\title{
Isolation of fresh endothelial cells from porcine heart for cardiovascular studies: a new fast protocol suitable for genomic, transcriptomic and cell biology studies
}

\author{
Olli-Pekka A. Hätinen, Johanna E. Lähteenvuo, Henna J. Korpela, Juho J. Pajula and Seppo Ylä-Herttuala*i(
}

\begin{abstract}
Background: Endothelial cells (ECS) play a key role in tissue homeostasis, in several pathological conditions, and specifically in the control of vascular functions. ECs are frequently used as in vitro model systems for cardiovascular studies and vascular biology. The porcine model is commonly used in human clinical cardiovascular studies. Currently, however, there is no robust protocol for the isolation of porcine heart ECs. We have developed a fast isolation protocol, which is cost effective, takes only $1-2 \mathrm{~h}$, and produces EC purity of over $97 \%$. This protocol is optimized for porcine hearts but can be adapted for use with other large animals.

Methods: Heart is washed by flushing with PBS, whereafter endothelial cells are detached by collagenase incubation and the cells can then be collected immediately after the incubation and plated within an hour after the heart is isolated from a pig.

Results: The swiftness of the protocol limits changes in the phenotype and RNA expression profile of the cells. Cells were identified as ECs with CD31 (PECAM-1) antibody immunostaining. Functionality of ECs were ensured with in vitro angiogenesis assay. The purity of the ECs was verified by using fluorescence assisted cell sorting (FACS) with the CD31 antibody.

Conclusion: We developed a new, fast, and cost-effective isolation method for pig heart ECs. Successful isolation of pure ECs is a prerequisite for several cardiovascular and vascular biology studies.
\end{abstract}

Keywords: Porcine heart, Endothelial cell, Isolation, Fresh tissue, Myocardial, Pig

\section{Background}

Endothelial cells (ECs) play a key role in the maintenance of vascular functions. Human umbilical vein endothelial cells (HUVECs) have served as a model system for many studies of the etiology of vascular diseases and the regulation of vascular homeostasis. These studies have provided significant knowledge about the functions of ECs and the development of vascular and malignant diseases. However, the phenotype and the functionality of ECs vary in different tissues [1,2]. Because of these specific differences, it is recommended to use ECs from the specific tissue in question. For that reason, ECs from heart are required for studies on myocardial diseases.

* Correspondence: seppo.ylaherttuala@uef.fi

A.I. Virtanen Institute for molecular sciences, University of Eastern Finland, Yliopistonranta 1E, 70211 Kuopio, Finland
Pigs are the most frequently used large animal for cardiovascular studies because of its similarities to human. However, to our best knowledge, no fast protocol for the isolation of pig heart ECs exists. Current isolation protocols are based on mechanically mincing and enzymatically digesting the heart tissue to a cell suspension, which is not feasible for a pig heart due to its large size [3]. Consequently, the mouse heart is usually used as the source of heart ECs. Even in the mouse heart cell suspension, most of the cells are fibroblasts and cardiomyocytes. Therefore, ECs must be labeled with antibodies to isolate them from the cell suspension. The labeling is expensive and timeconsuming taking usually at least $4 \mathrm{~h}$ [3]. Such protocols cause changes in EC transcription and phenotype [4-7], potentially changing tissue specific properties. To retain these specific properties, we developed a fast protocol to

(c) The Author(s). 2019 Open Access This article is distributed under the terms of the Creative Commons Attribution 4.0 International License (http://creativecommons.org/licenses/by/4.0/), which permits unrestricted use, distribution, and 
isolate ECs from porcine heart. The protocol takes only 1-2 $\mathrm{h}$ to complete (Fig. 1). In addition, the use of commercially available equipment allows this protocol to be adapted for use with other large animals [8].

\section{Results}

\section{Pre-medication and sacrification}

Five $\mathrm{ml}$ of Heparin (B. Braun, 2500 I.U./ml) was found to be critical for perfusion process. As an anticoagulant, Heparin makes removal of the blood easier. Intra-vascular (IV) injection of potassium chloride $(\mathrm{KCl})$ was used to arrest the heart in diastole, the phase in which the heart muscle is relaxed and veins are easier to perfuse.

\section{Isolation protocol}

The whole protocol is performed under sterile conditions and at room temperature (RT). However, all the solutions were preheated to normal pig body temperature $\left(37^{\circ} \mathrm{C}\right)$ to ensure best conditions for the cells. The whole protocol takes a maximum of $1-2 \mathrm{~h}$ to get the cells on the cell culture plates. The protocol provides approximately $2 \times 10^{5}$ to $3 \times 10^{5}$ endothelial cells from each heart. The swiftness of the protocol limits changes in the phenotype and RNA expression profile of the cells.

\section{Identification of endothelial cells}

Cells were identified as ECs with CD31 (PECAM-1) antibody (MCA1746GA, AbD Serotec) (Fig. 3 A) immunostaining. Tube formation is one of the key characteristics of ECs [9] and functionality of ECs were ensured with in vitro angiogenesis assay (Matrige ${ }^{\mathrm{mm}}$ GFR Membrane Matrix, \#356231, Corning, USA) (Fig. 3 B). Tube formation were observed in three different time points (p2, p3 and p5). The purity of the ECs was verified by using fluorescence assisted cell sorting (FACS) (Fig. 3 C). The CD31 antibody (MCA1746GA, AbD Serotec, USA) was used for the FACS assay.

\section{Endothelial cell culturing}

ECs were passaged maximum of 13 times, however, after passage 6 there were visual indications of the change in phenotype. There were no observed differences between cells isolated from individual pigs.

\section{Discussion}

The quickly growing field of cell and tissue studies requires more and more specific types of primary cells from various organs. Pig is the most frequently used large animal for cardiovascular studies because of its similarities to human. Therefore, we have focused on the isolation of pig heart endothelial cells instead of other species. There is no published protocol for quickly isolating pig heart ECs. Known methods are used mainly for mouse studies and are based on mechanically mincing and enzymatically digesting the heart tissue to a cell suspension. It is crucial that the isolation method is fast so it retains the specific properties ECs.

The main challenge in the protocol is EC recovery which may vary depending on how well cells are detached from each other. Occasionally, cells clog up inside the vessels obstructing the flow of the liquids, leaving many cells in the clogged vessels. This can be visually detected as the clogged region of the heart becomes heavily swollen. The exact reason for clogging remains unclear. However, when this does not happen, the isolation procedure provides large numbers of pure ECs, which are ready to be used for genomic, transcriptomic and cell biology experiments.

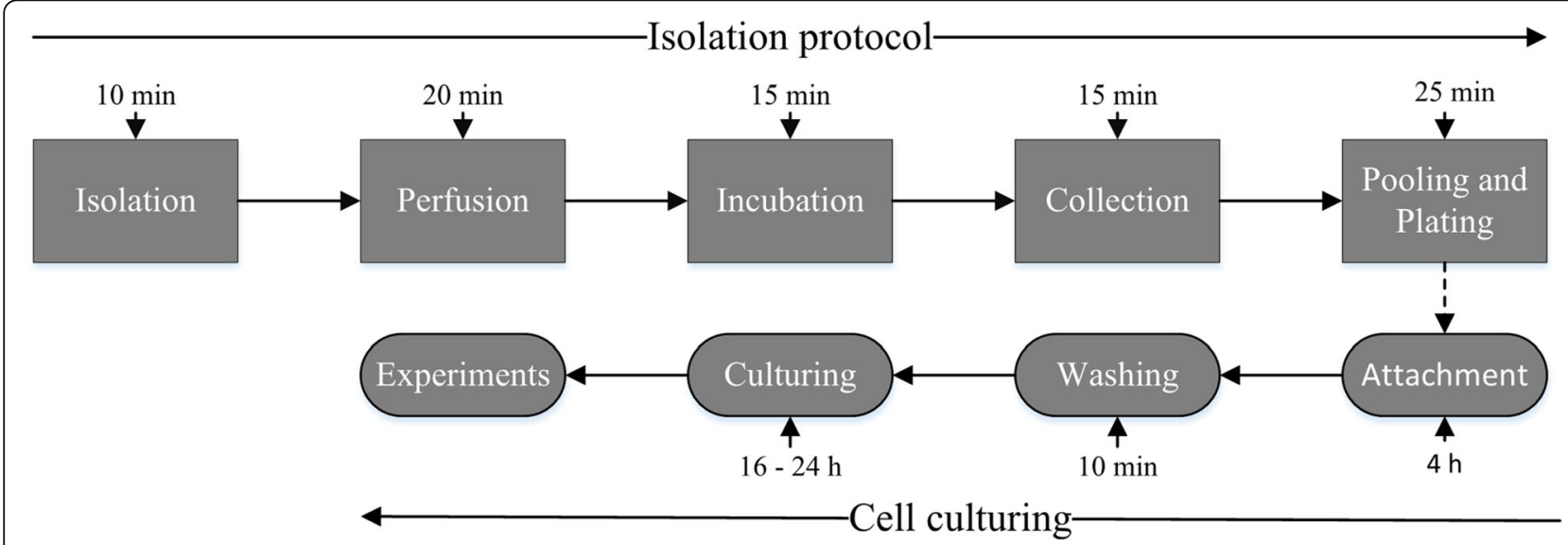

Fig. 1 Timeline of endothelial cell isolation protocol. Isolation protocol takes around $1-2 \mathrm{~h}$ to complete depending on the skill level of a scientist Isolation protocol includes: isolation of the heart, perfusion (setuping heart for perfusion, PBS perfusion and perfusion of Collagenase solution), Incubation $\left(37^{\circ} \mathrm{C}\right.$ water bath), collection of endothelial cells, pooling and plating (includes time needed for sentrifucation, removal of supernatant, pooling cells and plating them on fibronectin gelating-coated plates). Cell culturing includes: attachment of endothelial cells, washing and culturing time. Cells can be used for experiments or passaged when plates are $80-90 \%$ confluent 
Perfusion of only coronary arteries is challenging. Perfusion of the whole heart makes it possible that some of ECs could detach from leaflets of aortic valve or endocardium of the ventricles. However, we have established that shear stress in the coronary arteries lead to detachment of the ECs after the collagenase incubation. The pressure and flow rate on the ventricles are much lower than in the coronary arteries as the aortic valve is closed. In addition, concentration of collagenase will be decreased if any of it has flown in to the ventricles. In the future studies, it would be interesting to characterize the ventricular endocardial and leaflets endothelial cells as well.

The protocol can also be adapted for other large animals because of the equipment used are commercially available. The successful isolation of ECs is an essential source of cell cultures to be used for numerous studies, and therefore, it could also reduce the number of animal experiments.

\section{Conclusion}

We have developed a step-by-step method to isolate ECs from porcine heart. This protocol is a fast and inexpensive way to isolate ECs and offers new possibilities for the emerging fields of genomic, transcriptomic, cell and tissue studies in cardiovascular medicine and vascular biology.

\section{Methods}

\section{Isolation method}

All animal procedures were approved by The National Animal Experimental Board of Finland and carried out in accordance with the guidelines of The Finnish Act on Animal Experimentation. For this study, healthy, female pigs $(n=6$; Finnish Landrace-Yorkshire; Emolandia Oy, Finland) weighting $20-25 \mathrm{~kg}$ were used. After arrival at the FELASA accredited laboratory animal (The National Laboratory Animal Center of The University of Eastern Finland), animals were housed at stalls specifically intended for pigs. Clinical examination of the health status were performed at the arrival and on daily basis. Animals were kept in standard housing conditions. Diet and water were provided ad libitum.

Animals were randomly selected for the cell isolation. Pigs were pre-medicated with combination of atropine $(0.05 \mathrm{mg} / \mathrm{kg} \mathrm{im}$; Atropin, Takeda $\mathrm{GmbH}$, Austria) and azeperone $(8 \mathrm{mg} / \mathrm{kg} \mathrm{im}$; Stersnil, Elanco, USA). General anaesthesia were induced with propofol $(5 \mathrm{mg} / \mathrm{kg}$ iv bolus; Propolipid, Fresenius Kabi, Germany). Pigs were pre-medicated with $5 \mathrm{ml}$ of Heparin (B. Braun, 2500 I.U./ml). A single animal was used for each cell isolation. The isolation of heart and ECs were performed under sterile conditions. Pigs were sacrificed with an IV injection of potassium chloride $(\mathrm{KCl})$ and heart (approximately 250
$350 \mathrm{~g})$ was harvested and transferred to the fume hood at RT.

Heart was perfused using a Masterflex L/S infusion pump (Model 77,200-62, Masterflex, IL, USA) with a 19G needle attached to a Masterflex L/S 24 tube (Masterflex, IL, USA). The needle was carefully pushed into the aortic arch just above coronary arteries (Fig. 2). Aorta, pulmonary arteries and other blood vessels were clamped to provide pressure for liquid to flow into the coronary arteries. One to two litres of PBS (Dulbecco's Phosphate Buffered Saline, D8537, Sigma-Aldrich, USA) was used for perfusion to remove blood from arteries, veins and ventricles.

Next, the detaching solution (approximately $250 \mathrm{ml}$, $37^{\circ} \mathrm{C}, \quad 0.3 \mathrm{mg} / \mathrm{ml}$ [37.5 CDU/ml]) of Collagenase II [C6885, Sigma-Aldrich, USA] and IV [C5138, Sigma-Aldrich, USA]) was perfused into the vascular system of the heart and incubated for $15 \mathrm{~min}$. After the incubation, the heart was perfused with $800 \mathrm{ml}$ of PBS and the overflowing liquid containing ECs was collected into $50 \mathrm{ml}$ tubes. Tubes were centrifuged $\left(700 \mathrm{xg}, 4{ }^{\circ} \mathrm{C}\right.$ for $15 \mathrm{~min}$ ) and the supernatants were removed. Pellets were pooled by using $10 \mathrm{ml}$ of Complete Medium (1000 ml Dulbecco's Modified Eagle's Medium [Gibco, USA]; $4.5 \mathrm{~g} / \mathrm{ml}$ glucose; $200 \mathrm{ml} 20 \%$ FBS [Gibco, USA]; $0.5 \mathrm{ml} 1 \mathrm{M}$ HEPES pH 7.4 [Gibco, USA]; $10 \mathrm{ml}$ penicillin/streptomycin [Gibco, USA]; $5 \mathrm{ml} 100 \mathrm{mM} 1 \mathrm{x}$ Non-Essential Amino acids [Gibco, USA]; $5 \mathrm{ml} 100 \mathrm{mM}$ 1X Sodim Pyruvat [Gibco, USA]; $2.5 \mathrm{ml} 1 \mathrm{mML}$-glutamine [Gibco, USA]; $5 \mathrm{mg}$ Endothelial mitogen [Biomedical Technologies Inc., USA]; $2 \mathrm{ml} 500$ UI Heparin [B. Braun, Germany]). Plates were coated with $5 \mathrm{ml}$ of fibronectin $(10 \mu \mathrm{g} / \mathrm{ml}$, \#F2006, Sigma, USA)-gelatin $(0.5 \mathrm{mg} / \mathrm{ml}$, \#G6144, Sigma, USA) in PBS and incubated at $5 \% \mathrm{CO}_{2}$, $37^{\circ} \mathrm{C}$ for $30 \mathrm{~min}$. Excess fibronectin-gelatin was removed after the incubation. Cells were plated on fibronectin gelatin-coated $100 \mathrm{~mm}$ cell-cultured plates. The plates were kept at $5 \% \mathrm{CO}_{2}, 37^{\circ} \mathrm{C}$ for $4 \mathrm{~h}$ to let ECs to attach on the plates. The plates were then washed with $3 \times 10$ $\mathrm{ml}$ of PBS to remove the remaining red blood cells. After the washing, $10 \mathrm{ml}$ of Complete Medium was added to the cells. The medium was changed $16-24 \mathrm{~h}$ after the washing. Cells were passaged when the plates were 80 to $90 \%$ confluent. The isolation procedure provides large numbers of pure ECs (Fig. 3), which are ready to be used for genomic, transcriptomic and cell biology experiments.

\section{Immunostaining}

Endothelial cells (passage 3) were plated on Nunc ${ }^{\text {Th }}$ LabTek $^{\mathrm{mm}}$ II Chamber Slide ${ }^{\mathrm{Tm}}$ (154,523, Thermo Fisher, USA). Cell permeabilization was achieved by $15 \mathrm{~min}$ incubation with $0.1 \%$ Triton X-100 in PBS $(600 \mu \mathrm{l} /$ well). Primary antibody $(200 \mu \mathrm{l} /$ well, dilution 1:50, CD31 (PECAM-1) [MCA1746GA, AbD Serotec]) was incubated for $60 \mathrm{~min}$ 


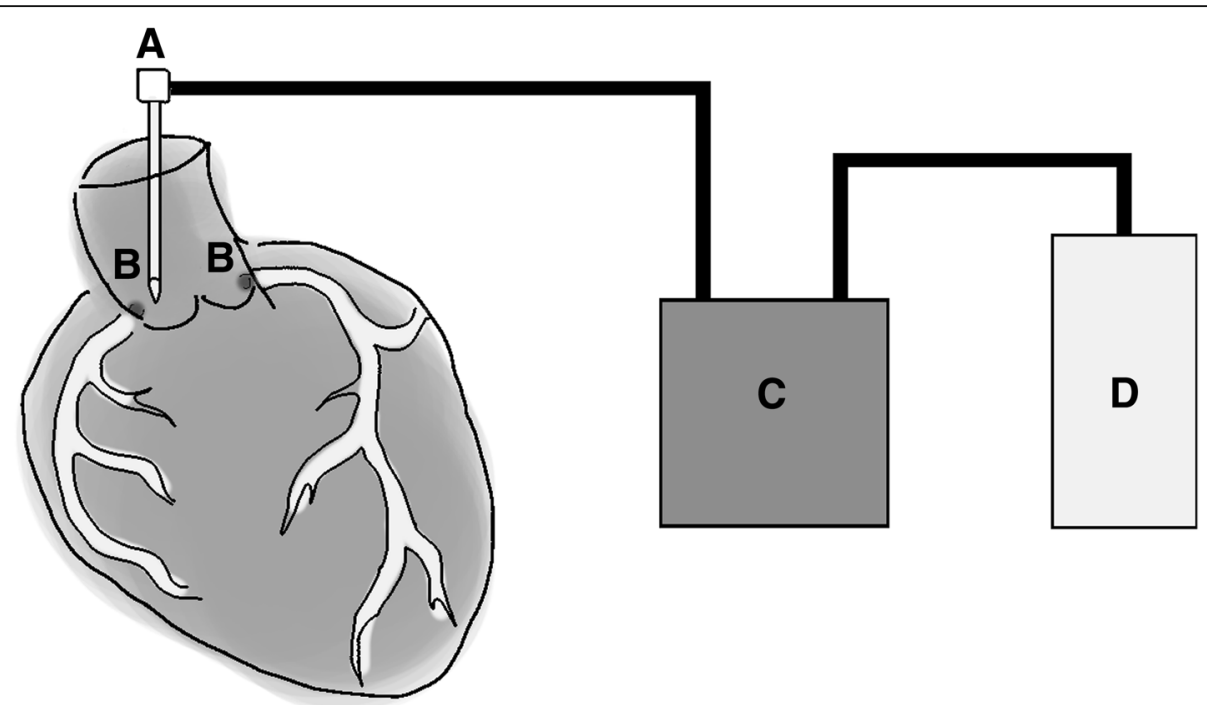

Fig. 2 Illustration of the endothelial cell isolation system. Firstly, the needle (a) placement is critical for a successful isolation. It should be located right above the openings of the coronary arteries (b) in aortic arch. A Masterflex L/S infusion pump (c) is started with a medium speed (400 ml/ min) to wash and fill the ventricles with PBS (d). After the ventricles are washed, the pump is stopped so that the aortic valves will be closed. The pump is restarted after $30 \mathrm{~s}$ with a low speed $(100 \mathrm{ml} / \mathrm{min})$ so that flowing liquid (PBS) will not push the valves open but flows into the coronaries instead. Aorta is closed with medical clamps. After that, you should feel pressure on the aortic arch and coronary flow should start. The perfusion is continued until the flushing liquid is clear. Image courtesy of Dr. Henna J. Korpela

at RT. Wells were incubated 15 min with $600 \mu$ l of PBS, $0.1 \%$ Triton X-100 in PBS and again with PBS. Secondary antibody Alexa Fluor $488(200 \mu \mathrm{l} / \mathrm{ml}$, dilution 1:200, A-21202, Thermo Fisher, USA) was incubated for $60 \mathrm{~min}$ at RT. Wells were washed again again with PBS, $0.1 \%$ Triton X-100 in PBS and PBS for 15 min and then stored with $600 \mu \mathrm{l}$ of PBS. Immunostainings with no primary antibody incubation were used as controls.

\section{Fluorescence assisted cell sorting (FACS)}

At passage 3, ECs were detached with trypsin and transferred into $15 \mathrm{ml}$ centrifuge tubes. Cells were centrifuged $600 \mathrm{xg}$ for $6 \mathrm{~min}$. Supernatants wa removed and cells were resuspended with $1 \mathrm{ml}$ of $2 \%$ PFA-PEM in PBS and incubated for $30 \mathrm{~min}$ at RT. After incubation, tubes were centrifuged $1000 \mathrm{xg}$ for $3 \mathrm{~min}$. Supernatant was removed and cells were washed with PBS and centrifuged as above.
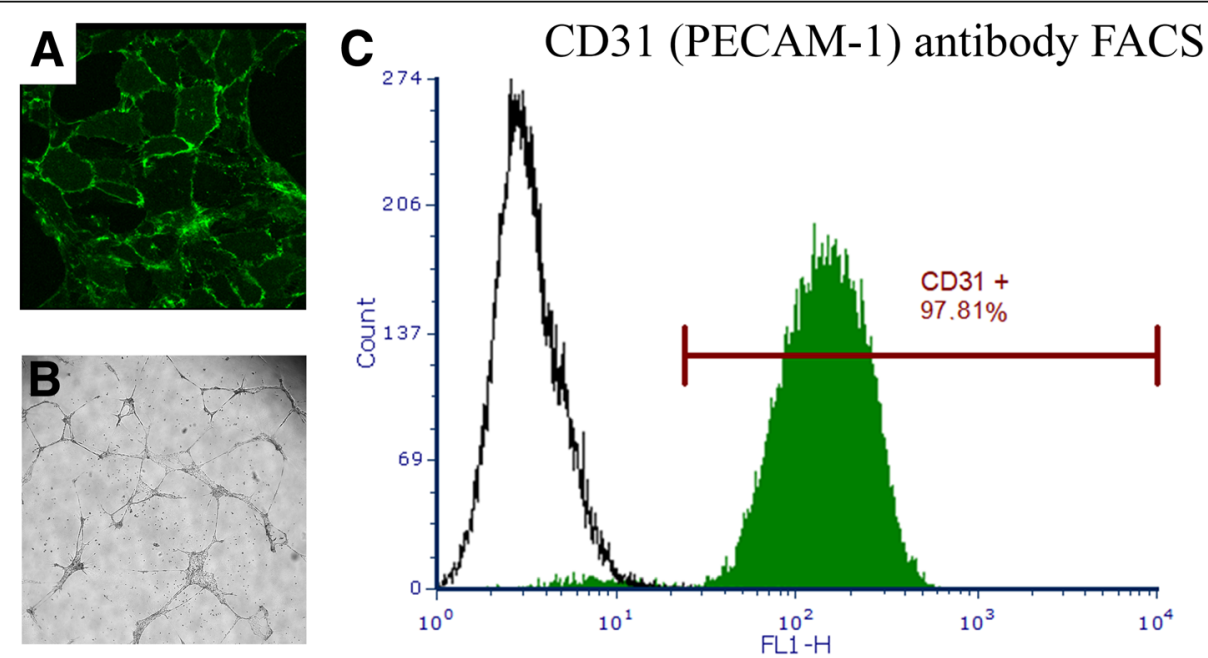

Fig. 3 Identification of functionality and purity of endothelial cells. a) Isolated cells were identified as endothelial cells by CD31 (PECAM-1) antibody (MCA1746GA, AbD Serotec) immunostaining (passage 3). b) One of the characteristics of endothelial cells is tube formation. Functional analysis of the cells was performed by using an angiogenesis assay (Matrige ${ }^{T M}$ GFR Membrane Matrix, \#356231, Corning) (passage 2). c) Purity of the cells was ensured by using fluorescence assisted cell sorting (FACS) resulting in purity of $97.81 \%$, which can be considered as a pure preparation of ECs (passage 2) 
$500 \mu \mathrm{l}$ of blocking serum (10\% FBS in PBS) was added to tubes and incubated for $30 \mathrm{~min}$ at RT. Tubes were centrifuged as above and supernatant removed. Cells were incubated $60 \mathrm{~min}$ at RT with primary antibody $(200 \mu \mathrm{l}$ of $0.5 \%$ FBS in PBS and $1 \mu \mathrm{l}$ of CD31 [MCA1746GA, AbD Serotec]). Tubes were centrifuged as earlier and supernatant removed. Cells were washed twice with PBS. $200 \mu \mathrm{l}$ of secondary antibody Alexa Fluor 488 (dilution 1:200, A21202, Thermo Fisher, USA) was incubated for $60 \mathrm{~min}$ at RT. Cells were centrifuged and washed as above. Cells were suspended with $750 \mu \mathrm{l}$ of PBS and analyzed with the fluorescence-activated cell sorter (FACSCalibur, Becton Dickinson, USA). Immunostaining, negative control and primary antibody control were included in the analyses.

\section{Tube formation}

Matrigel (Matrige ${ }^{\mathrm{Tm}}$ GFR Membrane Matrix, \#356231, Corning, USA) was thawn overnight at $4{ }^{\circ} \mathrm{C} .0 .289 \mathrm{ml}$ per well of Matrigel $(10 \mathrm{mg} / \mathrm{ml})$ was pipetted with cooled pipet heads on a cooled 24-well cell-cultured plates. The plate was incubated at $5 \% \mathrm{CO}_{2}, 37^{\circ} \mathrm{C}$ for $60 \mathrm{~min}$. The remaining liquid was carefully removed.

Cells were detached from 80 to $90 \%$ confluent $100 \mathrm{~mm}$ cell-cultured plates with $1 \mathrm{ml}$ of trypsin ( $1 \mathrm{~min}$ at $5 \%$ $\mathrm{CO}_{2}, 37^{\circ} \mathrm{C}$ ). Effect of trypsin was stopped by $5 \mathrm{ml}$ of Complete Medium and cells were collected into $15 \mathrm{ml}$ tubes. The amount of cells was calculated from cell suspension. Cell suspension was diluted to concentration of $500.000 \mathrm{cells} / \mathrm{ml}$. $300 \mu \mathrm{l}$ of diluted cell suspension was pipetted per well. Cells were incubated at $5 \% \mathrm{CO}_{2}, 37^{\circ} \mathrm{C}$ for $16 \mathrm{~h}$.

After the incubation, remaining liquid was removed from the wells. Cells were washed with PBS and fixed for $15 \mathrm{~min}$ with $300 \mu \mathrm{l}$ of $1 \%$ Glutaraldehyde-2\% PFA in PBS solution. Fixation solution was removed and storage solution (PBS) was added. Imaging of the wells was done with confocal microscope (Axio Observer Z1, Zeiss, Germany).

\section{Abbreviations}

CDU: Collagen Digestion Unit: EC: Endothelial cell; FACS: Fluorescence assisted cell sorting; HUVEC: Human umbilical vein endothelial cell; PFAPEM: cytoskeleton-protective buffer; RT: Room temperature

\section{Acknowledgements \\ The authors wish to thank Dr. Petri Mäkinen and Dr. Suvi Jauhiainen for guidance and the skillful staff at the LAC, especially Heikki Karhunen, Minna Törrönen and Riikka Venäläinen.}

\section{Ethics and consent to participate}

All animal procedures were approved by The National Animal Experimental Board of Finland and carried out in accordance with the guidelines of The Finnish Act on Animal Experimentation. Animals were kept in standard housing conditions in The National Laboratory Animal Center of The University of Eastern Finland, Kuopio.

\section{Authors' contributions}

$\mathrm{OPH}$ developed method, performed isolations, did all the experiments and was main writer of the manuscript. JL had a major part on developing process, helped with the most of the isolations. JP and HK helped with the isolations and writing the manuscript. SYH was a major contributor in writing the manuscript. All authors read and approved the final manuscript.

\section{Funding}

This study was supported by grants from The Finnish Foundation for Cardiovascular Research (salaries), ERC (salaries) and Finnish Academy Center of Excellence on Cardiovascular and Metabolic diseases (salaries, reagents and animal costs). Funding bodies did not have any role in the design or performance of the study, nor in the interpretation of the results or writing the manuscript.

\section{Availability of data and materials}

The datasets used and/or analysed during the current study are available from the corresponding author on reasonable request.

\section{Consent for publication}

Not applicable

\section{Competing interests}

The authors declare no competing interests.

Received: 3 January 2019 Accepted: 2 August 2019

Published online: 13 August 2019

\section{References}

1. Aird WC. Phenotypic heterogeneity of the endothelium: I. structure, function, and mechanisms. Circ Res. 2007;100(2):158-73.

2. Karsenty E, Barillot E, Tosser-Klopp G, et al. The GENETPIG database: a tool for comparative mapping in pig (Sus scrofa). Nucleic Acids Res. 2003;31 (1):138-41.

3. van Beijnum JR, Rousch M, Castermans K, van der Linden E, Griffioen AW. Isolation of endothelial cells from fresh tissues. Nat Protoc. 2008;3(6):1085-91.

4. Lacorre DA, Baekkevold ES, Garrido I, et al. Plasticity of endothelial cells: rapid dedifferentiation of freshly isolated high endothelial venule endothelial cells outside the lymphoid tissue microenvironment. Blood. 2004;103(11):4164-72.

5. Lee MYK, Tse HF, Siu CW, Zhu SG, Man RYK, Vanhoutte PM. Genomic changes in regenerated porcine coronary arterial endothelial cells. Arterioscler Thromb Vasc Biol. 2007;27(11):2443-9.

6. Januszyk M, Rennert R, Sorkin M, et al. Evaluating the Effect of Cell Culture on Gene Expression in Primary Tissue Samples Using Microfluidic-Based Single Cell Transcriptional Analysis. Microarrays. 2015;4(4):540-50.

7. Zaitseva M, Vollenhoven BJ, Rogers PAW. In vitro culture significantly alters gene expression profiles and reduces differences between myometrial and fibroid smooth muscle cells. Mol Hum Reprod. 2006;12(3):187-207.

8. Neumann B, Guo K, Paul A, et al. Perfusionists in the world of tissue engineering - a quick and easy method for safe isolation of huge quantities of porcine cardiomyocytes. Perfusion. 2007;22(2):137-42.

9. Decicco-skinner KL, Henry GH, Cataisson C, et al. Endothelial cell tube formation assay for the in vitro study of angiogenesis. J Vis Exp. 2014;10(91):1-8.

\section{Publisher's Note}

Springer Nature remains neutral with regard to jurisdictional claims in published maps and institutional affiliations.
Ready to submit your research? Choose BMC and benefit from:
- fast, convenient online submission
- thorough peer review by experienced researchers in your field
- rapid publication on acceptance
- support for research data, including large and complex data types
- gold Open Access which fosters wider collaboration and increased citations
- maximum visibility for your research: over $100 \mathrm{M}$ website views per year
At BMC, research is always in progress.
Learn more biomedcentral.com/submissions 